Number 2008-31, October 3, 2008

\title{
Oil Prices and Inflation
}

As oil prices have climbed over the last several years, the memory of the 1970s and early 1980s has not been far from the minds of the public or of monetary policymakers. In those earlier episodes, rising oil prices were accompanied by doubledigit overall inflation in the U.S. and in several other developed economies. Indeed, central bankers say they are determined not to let this experience recur, emphasizing that they intend to maintain their credibility with the public in securing low inflation and achieving stable and well-anchored inflation expectations. In pursuing these goals, a key measure policymakers often focus on is core inflation; this may seem surprising, since core inflation excludes energy prices, among other things. However, one justification for looking at a measure that excludes energy prices is that they are typically quite volatile; for example, after rising steadily and hitting a record of about $\$ 145$ per barrel in July, oil prices then fell to under $\$ 100$ per barrel in September. Temporary oil price increases do not tend to pass through to the prices of non-energy goods and services when the central bank is credible-that is, when inflation expectations are well-anchored-and, therefore, will not result in persistently higher overall inflation.

This Economic Letter examines the impact of rising oil prices on core inflation over the last decade for four economies: the U.S., the euro area, Canada, and the U.K. I find some evidence that rising oil prices have had a positive and significant effect on core inflation in the euro area, but I find no systematic evidence that rising oil prices have had a significant impact on core inflation in the U.S., Canada, or in the U.K.

\section{How do rising oil prices affect the inflation rate?}

Rising oil prices tend to affect the overall consumer price index (CPI) directly by raising its energy cost component, which includes the prices of energy-related items, such as household fuels, motor fuels, gas, and electricity. Among these, gasoline and fuel oil are directly derived from crude oil, so their prices follow oil prices very closely. An increase in the price of oil may also affect energy costs through the prices of other items that are close substitutes; for example, households and businesses may switch from oil-related energy items to natural gas, thus leading to an increase in its price. The extent to which rising oil prices translate into higher overall inflation through higher energy costs depends on their persistence. If they continue to rise, they may lead to sustained increases in the overall price level, that is, to an increase in the overall inflation rate.

Rising oil prices tend also to affect the core portion of the CPI indirectly, because energy prices represent a considerable portion of the production cost for many of the items in it, such as transportation services. In addition, if workers have to pay higher energy prices themselves, they may bargain for compensating wage increases, which also increases the production costs of items in the core CPI. The extent to which rising oil prices translate into higher core inflation through higher production costs depends, among other things, on how much they break into the overall inflation expectations of those who set prices and wages. In fact, if rising oil prices lead to higher inflation expectations over the longer term, rising energy and wage costs are more likely to be passed through in terms of rising consumer prices. In this case, rising oil prices may lead to sustained increases in the core portion of the CPI, that is, to an increase in core inflation.

However, once oil prices stabilize, as they have in recent months, the corresponding inflationary pressures will dissipate. As a result, both overall and core measures of inflation may decline, with the overall inflation rate likely to fall towards the lower rate of core inflation.

\section{Why focus on core inflation?}

In their efforts to secure a low and stable inflation environment, and therefore limit the impact of inflationary pressures emanating from rising oil prices, monetary policymakers pay close attention to core inflation for several reasons. One is that the exclusion of the volatile food and energy 
components makes it a more reliable indicator of the underlying trend in inflation. Fluctuations in the prices of food and energy may reflect exogenous shocks, that is, developments that are not inherent to the dynamics of the economy-for example, a drought may decrease the supply of grains, or a political conflict in an oil-producing country may decrease the supply of energy. Such developments often turn out to be only temporary and, therefore, are not typically reflected in the underlying trend in inflation, which represents the persistent component of inflation. In fact, over extended periods, the quantitative contribution of temporary fluctuations to the persistent component of inflation tends to disappear.

Because core inflation reflects more closely the persistent component of inflation, it also is a reasonably good predictor of future overall inflation. Blinder and Reis (2005) provided formal evidence of this property for the U.S. Specifically, using monthly data from 1987 to 2005, they found that core inflation predicts future overall inflation better than overall inflation itself. This property is particularly important for the management of monetary policy and for the timing of monetary policy actions. Typically, there is a delay between monetary policy actions and their effects on the economy; in addition, these effects normally show a certain degree of persistence. Therefore, when policymakers look at core inflation, they find a reliable and transparent indicator that helps them understand what the path of inflation is likely to be when their actions start taking effect.

The Federal Open Market Committee, which includes both core and overall inflation in its quarterly forecasts, is not the only policymaking body to pay attention to core inflation, even among banks that may use overall inflation as their main measure. For example, the Bank of Canada openly uses core inflation as its operational monetary policy target, even though CPI inflation is its explicit monetary policy target.

A further reason for policymakers to focus on core inflation is that it helps focus the public's attention on this measure as an indicator of what future overall inflation is likely to be. In this sense, those who set prices and wages can find core inflation to be a useful benchmark for their inflation expectations. For policymakers, therefore, focusing on core inflation may help influence long-run inflation expectations.
In light of these considerations, examining the impact of rising oil prices on core inflation helps understand how much, if at all, they have become embodied both in the underlying trend in inflation and in long-run inflation expectations, and, therefore, to what extent that may lead to persistently higher inflation.

\section{Assessing the effects of oil price increases on inflation} One way to examine the impact of rising oil prices on core inflation is to estimate a Phillips curve model. According to this widely used statistical relationship, current inflation depends on lagged inflation, on the lagged unemployment gap, and on a lagged measure of output supply shocks. Lagged inflation captures the degree of inflation persistence. The unemployment gap, defined as the deviation of the unemployment rate from its baseline value, measures inflationary pressures emanating from the labor market. The measure of output supply shocks captures inflationary pressures emanating from factors, such as oil price increases. Hooker (2002) estimated such a model for the U.S. with core inflation as the dependent variable using data from 1962 to 2000 and found that, while oil price increases had a substantial impact on core inflation until 1981, they had little impact thereafter.

To examine the impact of recent oil price increases on core inflation for the U.S., the euro area, Canada, and the U.K., I use two simple variants of the Phillips curve model specified by Hooker. Core inflation, the dependent variable, is defined as the percent change in core CPI over the past 12 months. Two explanatory variables are lags of core inflation and of the unemployment gap. Because some of these data series for the four economies are available only from the second half of the 1990s, the estimation sample is shorter than Hooker's and covers the period from January 1997 through May 2008. (The documentation for the estimations reported here is available upon request.)

The first variant includes as an explanatory variable lagged local-currency oil-price inflation, which is measured by the change in the local-currency price of West Texas intermediate (WTI) crude oil-this captures inflationary pressures arising from oil price increases. For the U.S, this variable is simply the change in the price of oil, given that the price of oil is denominated in dollars in global oil markets; for the other three economies, it is the difference between changes in the dollar 
price of oil and in the exchange rate of the local currency relative to the dollar. One implication of this is that exchange rate changes affect inflationary pressures arising from oil price increases. For example, with the euro, the Canadian dollar, and the British pound all appreciating relative to the dollar over much of the last few months, the increases in the corresponding exchange rates have dampened the increases in the local-currency prices of oil originating from the rise in the dollar price of oil. The second variant includes the lag of noncore inflation, which is computed as the difference between changes in overall CPI and core CPI. This variable represents an alternative measure of inflationary pressures emanating from both food and energy prices.

I find that for the U.S., Canada, and the U.K., both local-currency oil-price inflation and noncore inflation have had a small and statistically insignificant effect on core inflation. In contrast, for the euro area, noncore inflation has had a positive and statistically significant effect on core inflation. Specifically, the estimated coefficient relative to the lag of noncore inflation implies that a $10 \%$ increase in noncore inflation has led to an increase in core inflation a year later of a little more than $1 \%$.

Why have recent oil price increases, as measured by noncore inflation, had a significant impact on core inflation in the euro area and not in the other three economies? One potential explanation may have to do with the lower degree of competition in European labor and consumer-goods markets. For example, workers' unions represent a larger share of the labor force in the euro area, so they typically command more influence in bargaining wages with employers. As a result, in response to higher energy prices, workers are more likely to obtain larger wage increases, inducing, in turn, higher costs for businesses. As for consumer-goods markets, businesses in the euro area face a lower degree of competition, so they enjoy stronger price-setting power. Therefore, they may have fewer hesitations to pass on increases in production costs to consumer prices, leading to a more significant impact on core inflation.

\section{Conclusions}

This Economic Letter has examined the impact of oil price increases on core inflation for four economies during recent years. The estimation results lend support to the view that rising oil prices have had some impact on core inflation in the euro area, while having a limited impact on core inflation in the U.S., Canada, and in the U.K. While these results are not conclusive, they do lend some support to the notion that the strong emphasis that monetary policymakers in these economies have placed on maintaining their inflation-fighting credibility has been working. Specifically, in the face of the recent oil price increases, these results suggest that their efforts have been quite successful in anchoring long-run inflation expectations and securing a low-inflation environment.

\section{Michele Cavallo} Economist

\section{References}

[URL accessed September 2008.]

Blinder, Alan S., and Ricardo Reis. 2005.

"Understanding the Greenspan Standard." In The Greenspan Era: Lessons for the Future. A Symposium sponsored by the Federal Reserve Bank of Kansas City, pp. 11-96. http://www.kc.frb.org/PUBLICAT/ SYMPOS/2005/PDF/Blinder-Reis2005.pdf

Hooker, Mark A. 2002. "Are Oil Shocks Inflationary? Asymmetric and Nonlinear Specifications versus Changes in Regime." Journal of Money, Credit, and Banking 34 (May), pp. 540-561. 
P.O. Box 7702

San Francisco, Calif.

San Francisco, CA 94120

\section{Address Service Requested}

\section{AUTHOR}

\begin{tabular}{ll}
\hline $3 / 7$ & $08-09$ \\
$3 / 14$ & $08-10$ \\
$3 / 21$ & $08-11$ \\
$4 / 11$ & $08-12$ \\
$4 / 18$ & $08-13-14$ \\
$5 / 9$ & $08-15$ \\
$6 / 6$ & $08-16$ \\
$6 / 13$ & $08-17$ \\
$6 / 20$ & $08-18$ \\
$6 / 27$ & $08-19$ \\
$7 / 3$ & $08-20$ \\
$7 / 11$ & $08-21$ \\
$7 / 18$ & $08-22$ \\
$7 / 25$ & $08-23$ \\
$8 / 8$ & $08-24$ \\
$8 / 15$ & $08-25$ \\
$8 / 22$ & $08-26$ \\
$9 / 5$ & $08-27$ \\
$9 / 19$ & $08-28-29$ \\
$9 / 26$ & $08-30$
\end{tabular}

Assessing Employment Growth in 2007

The Corporate Bond Credit Spread Puzzle

Falling House Prices and Rising Time on the Market

Are Global Imbalances Due to Financial Underdevelopment...?

The Financial Markets, Housing, and the Economy

Small Business Lending and Bank Competition

Retirement Savings and Decision Errors: Lessons from Behavioral...

Did Large Recalls of Chinese Consumer Goods Lower U.S. Imports...?

Speculative Bubbles and Overreaction to Technological Innovation

Consumer Sentiment and Consumer Spending

Research on the Effects of Fiscal Stimulus: Symposium Summary

Monetary Policy and Asset Markets: Conference Summary

Can Young Americans Compete in a Global Economy?

Unanchored Expectations? Interpreting the Evidence from Inflation...

How and Why Does Age at Kindergarten Entry Matter?

Treasury Bond Yields and Long-Run Inflation Expectations

Regional Variation in the Potential Economic Effects of Climate...

Summer Reading: New Research in Applied Microeconomics...

The U.S. Economic Situation and the Challenges for Monetary Policy

The EMU Effect on the Currency Denomination of International Bonds
Regev

Christensen

Krainer

Valderrama

Yellen

Laderman

Armour/Daly

Candelaria/Hale

Lansing

Wilcox

Wilson

Dennis

Cascio

Huang/Trehan

Cascio

Christensen

Butsic/Hanak/Valletta

Doms

Yellen

Hale/Spiegel

Opinions expressed in the Economic Letter do not necessarily reflect the views of the management of the Federal Reserve Bank of San Francisco or of the Board of Governors of the Federal Reserve System. This publication is edited by Judith Goff, with the assistance of Anita Todd. Permission to reprint portions of articles or whole articles must be obtained in writing. Permission to photocopy is unrestricted. Please send editorial comments and requests for subscriptions, back copies, address changes, and reprint permission to: Public Information Department, Federal Reserve Bank of San Francisco, P.O. Box 7702, San Francisco, CA 94120, phone (415) 974-2163, fax (415) 974-3341, e-mail sf.pubs@sf.frb.org. The Economic Letter and other publications and information are available on our website, http://www.frbsf.org. 